\title{
The Salvific Dimension of Time in the Christian Liturgy
}

\author{
DANIEL BRZEZIŃSKI \\ Nicolaus Copernicus University, Toruń \\ danbr@op.pl, ORCID: 0000-0003-4680-3055
}

\begin{abstract}
This paper discusses the relationship between time and salvation that exists in the Christian liturgy, in which time possesses two characteristics. One is its sacredness, and the other is a special property that does not exist outside the liturgy but derives directly from its anamnetic dimension: it is a "medium" and an "existential context" of the real salvation delivered and still being delivered by Christ. The author begins with a reflection on time in cultural anthropology and the history of religion, demonstrating unambiguously that, since the earliest of days, disparate cultures and religions have shared the conviction that time is sacred. He then goes on to address the biblical concept of time which has fundamentally contributed to a fuller understanding of the essence and nature of liturgical time as the кaıpós of salvation. It is in the liturgy of the Church-the final earthly stage in the history of salvation-that the salvific, effective and real encounter between God's eternity and human life takes place. The Christian liturgy is an otherworldly act of salvation in worldly space and time, a manifestation of the "fullness of time." The paper also attempts to offer a preliminary juxtaposition of the theological understanding of liturgical time with the findings of modern physics concerning the understanding and description of time. This may serve to stimulate further, more in-depth biblical and theological (and in particular theologico-liturgical) reflection on the phenomenon of time, and perhaps even a new look at the phenomenon of time on the part of modern physicists.
\end{abstract}

Keywords: time, kaıpóc, eternity, salvation, liturgy, anamnesis

In different academic disciplines (including, first and foremost, philosophy and the sciences), there exist different understandings of time and diverse concepts of time as one of the basic dimensions of human existence. With the advancement of research, especially in natural sciences, the terminology has also undergone many changes, with traditional notions taking on new meanings. The term "time" has multiple connotations in theological reflection, too. Furthermore, it has different meanings in popular understanding in different cultures. ${ }^{1}$

In this paper, we will be focusing our attention mainly on the concept of time as a sacred category, or more specifically, on the relationship between time and salva-

1 See Zachariasz, "Czas jako kategoria"; Gale, The Language. A broad bibliography on the notion of "time" and on the diverse understandings of time in European literature (especially in the theological aspect) can be found in Rosso, Il segno del tempo, 23-54. 
tion. In the Christian liturgy, time is characterized not only by its sacredness, but also by a special property that does not exist outside the liturgy and derives directly from its anamnetic dimension: it is the "medium" and the "existential context" of the real salvation delivered and still being delivered by Christ. ${ }^{2}$ Therefore, our goal will be to reveal the theological and historico-salvific nature of liturgical time.

Considering the above, our reflection on time in the liturgy would be incomplete without an analysis of-if one were to use the terminology once proposed by Mircea Eliade $(\dagger 1986)$ - the relationship between "profane time" and "sacred time." ${ }^{3}$ To that end, we will be presenting - in what is obviously a very synthetic manner-the reality of time from the perspectives of cultural anthropology and history of religion. Even in the ancient times, many cultures and religions known to us shared the conviction that time was sacred, marked by the "presence" of deities and various natural phenomena which were often inexplicable at the time. Moreover, it was believedwhich is of particular importance to this study-that there existed a ritual possibility of returning to the divine stories $a b$ origine as described in nearly all mythologies.

We will also revisit the biblical concept of time as the one which-being a product of the Divine Revelation-has determined the understanding of time in the liturgy of the Church. ${ }^{4}$ Liturgical time is salvific time, a continuation of the history of salvation; time in the liturgy is the "history of salvation in action": "here" and "now." As Achille M. Triacca (†2002) wrote, liturgical time is God's time in Jesus Christ in the same manner as space and every being are God's. ${ }^{5}$ Within that understanding, the time in which the daily existence and the present enter eternity is also a period of actualization of one's personality through the realization of transcendent values, especially those of a sacred nature.

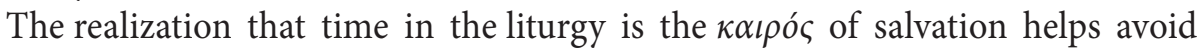
the reduced-erroneous and in a way stereotypical-yet sadly still quite common understanding of the liturgy of the Church solely as a set of cultic human actions performed in a specific spatiotemporal reality. Contrary to that understanding, the liturgy is, above all, an anamnesis of the Mystery of Christ, a real and effective presence of salvific events. Liturgical anamnesis is an objective remembrance and actualization hic et nunc of the Paschal Mystery of Christ, an objective reminder of the past, but also an anticipation of the future, that is of the heavenly liturgy. Even

2 For a discussion of the anamnetic character of the Christian liturgy as its primary historico-salvific dimension, see Brzeziński, "Chrystus wczoraj i dziś." A number of arguments taken from that comprehensive monograph have served as a starting point for this paper.

3 See Eliade, Mythes; Eliade, Aspects du mythe.

4 At this point, it is already worth noting (with a certain degree of simplification) that the cyclic concept of time is essentially cosmocentric, whereas the linear concept is essentially theocentric. By emphasizing the fact that the world was created ex nihilo, theocentrism does away with the cyclicality of the world that is commonly derived from polytheism.

5 Cf. Triacca, "Tempo e liturgia," 1494. 
though the salvific events that the Church celebrates every day-especially in the Eucharist and in the Liturgy of the Hours-took place once and only once in specific spatiotemporal circumstances, and historically have never reoccurred and will not reoccur, thanks to the presence and action of the Holy Spirit, they become present hodie in a sacramental manner every time they are celebrated in the liturgy: in mysterio, and not just in the salvific effects. ${ }^{6}$ After all, the first and main Liturgist is none other than Christ Himself: resurrected and seated at the right hand of the Father.

Finally, we will attempt to juxtapose-at least in a preliminary manner-the theological understanding of liturgical time with the findings of modern physics that concern the understanding and description of time. To some researchers and readers, this juxtaposition (liturgy vs. physics) and the departure from a strictly theological reflection may seem unnecessary or even methodologically dubious, since we will be exploring two completely different ontic planes. Nevertheless, it may act as a stimulus for a further, more in-depth biblical and theological (and in particular theologico-liturgical) reflection on the phenomenon of time, and perhaps even for a new look at the phenomenon of time from the modern physicists. ${ }^{7}$ As is common knowledge, modern physics denies the existence of objective time and interprets time as a coordinate in four-dimensional space. ${ }^{8}$ It has also been argued that comprehending the nature and characteristics of time is now the most important task faced by physics. ${ }^{9}$

\section{Attempts to Define and Classify Time: Certain Limitations and Difficulties}

When writing about time, one should first endeavor to provide a definition (as demanded by the fundamental tenets of scientific methodology). However, any attempt

6 For a broad discussion of this subject, see Brzeziński, "Chrystus wczoraj i dziś," 157-227; Brzeziński, "Liturgia skarbem Kościoła”; Brzeziński, "Wokół teologicznego sensu liturgii."

7 Such an interdisciplinary dialogue between the sciences and the humanities (including theology) as a "bridge-from both sides-for mutual understanding" was called for by Grzegorz Karwasz in his latest book (Scienza e fede); see also McLeish, "Commentary."

8 In the Polish literature on the subject, a valuable reflection on this issue was undertaken nearly thirty years ago in Liszka, Wplyw nauki, a book to which we will be making many references. The author broadly discusses the impact of the concept of time (including the new physical theories of time) on the theological reflection concerning the following issues: the relationship between eternity and worldly existence; the issue of time in the mystery of the creation of the world; the relationship between temporal history and God's eternity; the meeting of time and eternity in the Mystery of Christ and in the liturgy; and the temporal structure of death, the situation between death and the end of time, and eschatological events. In his monograph, he also included a comprehensive bibliography on the issue of time in the different fields and disciplines of science. See Liszka, Wplyw nauki, 209-231. Nevertheless, there is still a shortage of relevant works of a strictly theological-liturgical nature. See Tempczyk, "Czas we współczesnej fizyce," 244. 


\section{DANIEL BRZEZIŃSKI}

to define time in a precise manner is destined to fail due to the fact that an awareness of time is essential for capturing it. As a consequence, it is not possible to define time without actually using the category of time (as required for a methodologically correct definition). ${ }^{10}$ Thus, one is faced with a circular definition. The notion of time is, by its very nature, transcendent; it is a fundamental precondition for the very existence of transcendentality.

It is very difficult or even impossible to define time due to the fact that a human being cannot perceive this phenomenon from a certain perspective. While time can of course be measured, it cannot be observed from a distance. In other words, one cannot see its beginning or end, or the simple or intricate moments of its development. Furthermore, owing to its very nature, time passes regardless of whether one is thinking about it or trying to forget about it. And finally, time cannot be captured by any of the human senses, be it hearing, sight, taste, smell, or touch, even though human beings exhibit tendencies-both in the spiritual sphere and in the rational sphere-to "dominate time" and to "conquer time."11

As the ancients already noted, the moment one attempts to divide time into the past, the present and the future as these terms are commonly understood, one realizes that the past no longer is and the future is yet to be; only the present can be said to exist. However, the present-in the more exact meaning of the word-is not a period that encompasses the past and the future, since these parts of time do not exist.

One may only have a direct experience of the present, and it is the reflections resulting from this state of affairs that have shaped our idea of time. The conviction that the passage of time is absolute does not seem to derive directly from experience (which may be subject to interference from factors such as one's degree of concentration or current mental and physical state), but rather from a reflection upon that experience. In addition, there is a fundamental difference between the understanding of time by a modern person living in the Western civilization and the sensation of time in primitive communities or even in the ancient cultures that produced highly advanced civilizations. ${ }^{12}$

It is important to distinguish at least three aspects of time: the ontological aspect, the psychological aspect and the epistemological aspect. In the most general terms, the ontological aspect is about the mode of existence of time, the psychological dimension is about examining time in terms of how it is being experienced by human beings, and on the epistemological (methodological) plane, the issue of time is being

\footnotetext{
Cf. Baumgartner - Wildfeuer, “Czas," 70-71.

Cf. Klein, Czas, 8-9; Kijas, "Czas i kalendarz," 9-13; Auf der Maur, Le celebrazioni, I, 36-38.

Cf. Whitrow, Czas w dziejach, 19-23.
} 
discussed in an attempt to show the way to the understanding of time and to provide a definition of time. ${ }^{13}$

There are many ways in which temporal planes can be classified. One such attempt at systematization was undertaken by the late outstanding Polish theologian Czesław Bartnik (†2020), who presented a classification of ontically different types of time based on the environment in which a given type of time is passing. And thus, cosmic time is an internal category of the universe and the first consequence of God's creation of the world (earlier even than space in the ontic aspect). Earthly time (or geobiological time) is associated with the genesis, formation and development of the globe ad intra. This type of time is essentially linked to the nature of different created beings and directed towards some primordial fulfillment. Event time, in turn, is associated with historical events and processes. Individual events impart a certain value to time, influence one another, and have significance to the future. The salvific value of event time is being analyzed by the contemporary theology of history. The next category, social time, is in a way "post-physical" and "post-biological," although it has the property of being real. It is associated with the perception of time and lifestyle in a given society. And finally, there is personal time, that is time in which a human being develops towards the fullness of a person; it is both subjective and objective at the same time. Personal time plays the most important role in theological reflection. All other types of time are significant in the context of the role they play towards man and the history of salvation. ${ }^{14}$

\section{Time as a Sacred Category in Anthropological and Religious Reflection}

In cultures which are long gone, cultures which still exist but stopped at early stages of civilizational development and cultures of the present day alike, there has been a general awareness that the category of time possesses a certain reality, and therefore attempts have been made to define this category using concepts and terms available to each of these cultures or civilizations. ${ }^{15}$ For people of archaic communities, the events that had occurred $a b$ origine could be recreated by the "power of rituals"

13 Unfortunately, many encyclopedias and textbooks (especially those of a general nature) fail to account unambiguously for the complexity of the issues associated with the notion of time. Such publications predominantly focus on selected aspects only (which is natural in the case of more specific or monographic works).

14 See Bartnik, Chrystus jako sens, 259-260; cf. Liszka, Wpływ nauki, 22-25; Augustynek, Natura czasu, 23-38.

15 Cf. Liszka, Wpływ nauki, 14-17. 
in which the acts once "performed" by gods, heroes and ancestors were remembered and reactualized. ${ }^{16}$

The magnificent and sacred past represented by myths-especially in the ancient mystery religions - was more than a reality gone by. ${ }^{17}$ It was and still is a living source of existence present in every moment, "here and now." The sacred past, the "time of the gods" in the words of Walter F. Otto ( $† 1958)$, is an "image of eternity obscured to humans"; it is "obscured" since it is too vast and transfixing for human perception. Time is an "emulation" of eternity. In this context, one cannot speak of the past in the past tense, which is aptly expressed by the Greek perfectum: the past "is happening" in the present and "is projected" into the future. In all primitive communities and in every authentic religious culture, the dead ancestors (precisely by virtue of being dead) are part of the most dignified reality, the sphere from which every solemn action originates and in which life opens its primeval depth, and thus "stand in the reality of the true revelation of the eternal now." 18

In the consciousness of the participants, the experience and celebration of myths through rites performed under the protection of signs resulted in an "emergence" from the chronology of time and the profanum of the present and an "entry" into an entirely different time, "sacred time," "time of origin," and yet time which can be restored. This was not only about the recalling of mythological events, but also about their reenactment, including the "presence" of the mythical heroes. The heroes were made present again, and thus the participants in the rites became their "contemporaries." This also meant that the latter were no longer living in a time in which events were arranged chronologically, but in "primordial time" in which the events being celebrated had taken place for the first time. In that sense, one may speak of the "great time" of the myth, that is time which was extraordinary and sacred; time in which something new, powerful and significant became fully revealed. Those participating in the mysteries desired to repeat, restore and relive that time as often as possible in order to encounter supernatural beings and share-as Eliade described it-in the spectacle of divine creation. Religious rites are "festivals of remembrance," a regaining and anamnesis of the past, whereas forgetting what happened in illo tempore is the main obstacle on the way to knowledge and salvation. ${ }^{19}$

16 See Brzeziński, "Chrystus wczoraj i dziš," 73-117; Brzeziński, "The Notion of Myth"; Brzeziński, "Rytualizacja mitu."

17 One could point to many such religions in this context. For information on the Greek Eleusinian mysteries, see Kerényi, Eleusis; see also Mondin, Mito e religioni.

18 See Otto, Theophania; Otto, Mythos und Welt. In the Polish literature on the subject, Walter F. Otto's views which are relevant to this discussion are presented in a synthetic manner in Juszczak, Pani na Żurawiach, I, 100-101; cf. Brzeziński, "Chrystus wczoraj i dziś," 93-95.

19 Such conclusions are clear in Mircea Eliade’s research. They have been formulated, for example, in Eliade, Aspects du mythe (as cited above). 
Remembering and recreating the events of ancient times-which is a form of "anamnesis" - helped the primitive man to distinguish and remember what was true and real. ${ }^{20}$ The cyclical repetition of "paradigmatic gestures" resulted in the uncovering of things which were lasting and permanent in a world of general impermanence. By repeating the events that had occurred $a b$ origine, man gained the reassurance that something existed in an absolute manner. This "something" belonged to the sphere of the sacrum, which-despite existing above the human world-is accessible to the human religious experience through the rites being celebrated. The experience of what the gods, heroes and ancestors had gone through in illo tempore resulted in the sacralization of the human existence. The transcendent world of the gods, heroes and mythical ancestors was reachable due to the fact that the members of the archaic communities did not recognize the irreversibility of time.

The ancients' conviction that a past event could continue to exist was rooted, among other things, in their concept of cyclic time, which presumed that repeatability of events was in the nature of things. Today, in the modern era, mainly under the influence of Judaism and Christianity, the commonly accepted concept is that of historical time, or linear time, where events occur only once and are unique in a historical sense. However, this does not by any means imply-as is particularly obvious in Christianity and the Christian liturgy-that such events cannot be repeated on a different plane and in a different real dimension.

It is also worth adding that in Christianity, by the very fact that it is a religion, categories of mythical thinking and elements of mythical behavior (in the positive sense of the word) are used. For that reason, liturgical time itself has always been understood in Christianity as the "periodic rediscovery of the illud tempus of the beginnings," or "that time" of the Incarnation, Passion, Death, Resurrection and Ascension of the Divine Founder.

The distinction between "profane time" and "sacred time" in religions (and in Christianity in particular) leads to the cutting out of the different "fragments" of time in the continuity of "profane duration" so that sacred time can fit within it. These fragments of sacred time retain continuity between one another, or even-as one could say-form such continuity. Typically, these "hierophanic fragments" of time reoccur every year. In the sense that they constitute some form of "duration" with a sacred structure, one might say that they "stretch out," forming the one and only "time" across years and centuries. In religion, this periodicity means, above all, the constant use-here and now-of mythical time made present. It means the use of transhistorical events which cyclically and, at the same time, continually occur here

20 The term "anamnesis" is placed in quotation marks due to the fact that anamnesis as a real and effective presence of the mystery being celebrated can only occur in the Christian liturgy. Liturgical anamnesis is ontically different from the "anamnesis" present in the ancient mystery religions, although in this case, one might speak of a formal (and only formal) analogy between the understanding of anamnesis in the known mystery cults and the anamnesis of the Mystery of Christ that occurs in the Christian liturgy. 
and now; since theophanic time repeats itself, they occur in a real manner and thus become the present, current time. In other words, it means the "eternal present" of salvation in cosmic time. ${ }^{21}$

\section{The Biblical Concept of Time}

In the Holy Scripture (and, consequently, in the liturgy of the Church), the issue of time begins with the first sentence of the first book of the Bible ("In the beginning God created the heavens and the earth"; Gen 1:1), then continues through the "fullness of time" in the Mystery of the Incarnation (cf. Mark 1:15; Gal 4:4), and ends with the "passing away of the first heaven and the first earth" described in the vision of the new creation and the heavenly Jerusalem of Messianic times in the Book of Revelation, culminating in Christ's reassurance of "Surely I am coming soon" and our plea of "Amen. Come, Lord Jesus!" (cf. Rev 21:1 to 22:21). What happens in time-that is between these two critical events-is the gradual unfolding of God's salvific plan created "before the foundation of the world" (Eph 1:4), and thus before the beginning of time. ${ }^{22}$

It has commonly been assumed that a linear concept of time is typical of the Bible, beginning with the oldest books of the Old Testament. The linear time of the Old Testament is headed towards the coming of the Messiah and the Day of Yahweh. While this manner of understanding time did in fact distinguish the People of the Old Covenant from their neighboring nations, the above opinion appears to be a certain simplification, since there is a great wealth of ideas concerning time in the Bible. The Western, Christian way of interpreting time (which is essentially linear) was unconsciously attributed to Israel, especially by the earlier biblical commentators. Now, although not without some difficulty, there has been a shift towards

21 The term "cosmic time" is used in cultural anthropology and history of religion to describe the dimension of the universe in which the duration of changeable things and the rhythmic repetition of phases of nature are measured. This is the time of calendars, divided into months, weeks and days. Cosmic time is objective and neutral, which means that it is independent of man. The rhythm of that time had been noticed by even the most primitive men before they began to reflect in any way on the passing time that encompassed events from their personal, family and social life. Thus, historical time was "born," a specific form of cosmic time experienced by specific people, a specific history of a specific person. Cf. Bergamini, Cristo, festa della Chiesa, 54-55; Augé, L’anno liturgico, 30-33.

22 Cf. Nadolski, Leksykon liturgii, 281; Augé, L'anno liturgico, 27. In this context, we would also like to point to a number of articles on the different aspects of the biblical understanding of the nature of time and eternity published in Verbum Vitae 35 (2019), together with the relevant bibliography: Napora, "Czas w kapłańskim opowiadaniu”; Jasiński, "Prorockie ujęcie czasu”; Parchem, "Periodyzacja historii"; Kręcidło,

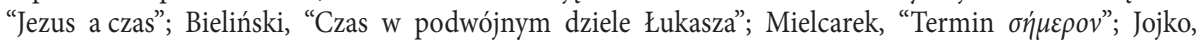
"Eternity and Time”; Karczewski, "Znaczenie terminu $\ddot{\omega} \rho \alpha$ "; Siemieniec, "Teologiczna funkcja”; Szram, "Wszystko ma swój czas." 
the view that in the ancient Israel, the reality of time was often understood in a manner different from today's understanding, and therefore that the Bible-contrary to established ways of thinking - is not constrained to the simple patterns of linear or cyclic time. ${ }^{23}$

Time in the Bible has a sacred dimension, one which it did not have in the minds of the ancient Greeks or Romans, even though their beliefs were also centered around a calendar of festivals, and their philosophers pondered on the relationship between time and eternity. When time relates to the internal history of the world, biblical texts unambiguously regard it as a line pointing towards the future. Nevertheless, one cannot overlook the fact that from God's perspective, the line describes a circle. ${ }^{24}$

In accordance with the Old Testament concept of time, which emphasizes not so much time itself as it does the events that occur within it, Christ's coming to the world brought with it the "fullness of time" (cf. Gal 4:4; Eph 1:10). Jesus's earthly life-understood as the fulfillment of the world's expectations-also ushered in a new attitude towards the reality of the world, including time. ${ }^{25}$

In the New Testament, the linear model of time as a harmoniously flowing stream is linked to the nonlinear model of the mysterial actions of Jesus Christ, the Word made Flesh. The Son of God governs time and shapes it, heading towards his "Hour"; yet, he also enters time and subjects himself to its effects. The Incarnation is the mystery of the reception of time by the Word, and the Passover means the bestowing upon time of a new quality. Furthermore, by being seated "at the right hand of the Father," Jesus as the God-Man introduces a new dimension, a dimension of a different kind into the cosmic space-time. As Jesus's story unfolds, His relationship to time is transformed, and so is - in a way-the structure of time itself. Thanks

23 Searching for biblical concepts of time (while realizing that the term "concept" itself is not the most appropriate one in this context as there are virtually no theoretical discussions of time in the Bible), one must remember that thousands of years ago, when the books of the Holy Scripture were composed, the modern models of time-mainly created in modern-era natural science-were not known. The thinkers of that time generally distinguished between "linear time" and "cyclic time," paying less (or hardly any) attention to more complicated time patterns. The ancient Hebrews' way of thinking was thoroughly practical and focused primarily on deliberate conduct in life. Thus, it was far from any metaphysics, although there have been attempts by biblical scholars to look for subtexts, especially in the prophetic books. See Jankowski, "Biblijna koncepcja czasu," 21-23; Augé, "Teologia dell'anno liturgico," 15-17; Bruni, "La concezione biblica"; Perani, "La concezione del tempo"; Perani, "La concezione ebraica"; De Vries, "Il tempo nella Bibbia".

24 As noted by Czesław Bartnik, Christianity has always maintained that the world came from God and will return to God, thus "coming full circle." The modern-day physical theories, however, establish a multidimensional model of space-time in which the flow of time is determined by a multitude of factors, thus going beyond the dispute on the linearity or cyclicality of time. Naturally, a comprehensive view of time does not negate its "internal forms" that appear in biblical thought. On the contrary, it emphasizes all the "substructures" that exist within it: linear, cyclical, and other. Cf. Bartnik, Teilhardowska wizja dziejów, 155; Liszka, Wplyw nauki, 9-10; Cecolin, "Le nuove concezioni."

25 Cf. Liszka, Wplyw nauki, 67; see Burns, "Two Words for 'Time"; Glasswell, "The New Testament View"; Manek, "Biblical Concept of Time"; Neuenzeit, "Zeit," 1534-1539. 


\section{DANIEL BRZEZIŃSKI}

to the Paschal Mystery of Christ, time has "entered" eternity, and God has entered the earthly world in a new way. ${ }^{26}$

Unlike the writings of the Old Covenant, the books of the New Testament more strongly emphasize the structure of time as a reality that objectively exists; one that is realistic and can be cognized by the human mind. The salvific events are no longer just an anticipation; they are also being experienced within the framework of a chronologically structured history. Through Christ and in Christ, there occurs a passing from the old time to the new time, although the latter has not yet reached its fullness. The internal structure of time itself is also changing, and the transformation eventually involves the transition of worldly structures into eternal ones. ${ }^{27}$

In the New Testament, there are essentially three terms known in classical Greek

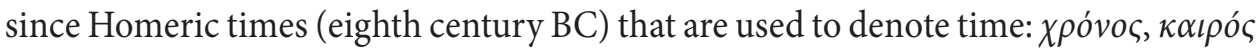
and $\alpha i \omega v^{28}$

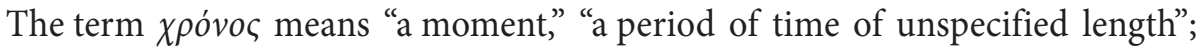
it is "time (in general)," "time which passes," "objective" time or, in other words, time which can be measured in physics or astronomy.

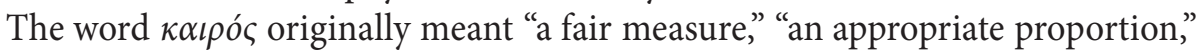
"something appropriate," "something defining," "something suitable." This is time understood as "an opportune moment," "a point in time which coincides with the attainment of a goal," "an appropriate moment" to make important decisions, "an opportunity" that offers great possibilities and a favorable situation. Under certain circumstances, it is synonymous with the adverb "now." In the language of religion, this word most often means the time of God's coming, the moment when God redeems, the right moment for one to convert and change one's life, the decisive "hour" of man and-as may be added in the context of this paper-the "hour" of salvific hope. ${ }^{29}$

And finally, there is the term $\alpha i \omega v$ (which, in classical Greek, sometimes means "lifetime," and in other cases, a "generation"), which is used in the Bible as a, so to

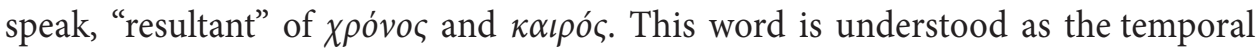
dimension of the human life that is incorporated into God's time, a dimension of human life that transcends this life and reaches into the past and into the future. This is not some indefinite time, a moment in time, or even a specific time, but rather

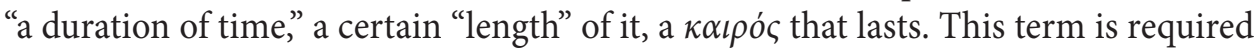
to explain the historical and eschatological concept of the New Testament. In addition, it points to the linear concept of time in the New Testament: yesterday-today-tomorrow; past-present-future.

\footnotetext{
26 Cf. Liszka, Wplyw nauki, 79-80; Rosso, Il segno del tempo, 40-43; see Kręcidło, „Jezus a czas," 174-181.

27 Cf. Liszka, Wptyw nauki, 72; Bartnik, Historia ludzka i Chrystus, 56.

28 See Augé, L'anno liturgico, 33-37; Léon-Dufour, Stownik Nowego Testamentu, 205-208; Jankowski, „Biblijna koncepcja czasu," 30-31.

29

See Bielecki, "Kairos (1)," 334; Stachowiak, "Kairos (2)," 334-335; Bielecki, "Kairos (3)," 335-337.
} 
Apart from the above, one may also encounter other terms referring to time in the New Testament, such as $\dot{\eta} \mu \varepsilon \dot{\rho} \alpha$ ("day"), $\omega \rho \alpha$ ("hour") and-in a Latinized formeon ("a period of time that extends or lasts"). In a biblical sense, the last of these terms means "a time period," "an age in the history of the world" or simply "a century" (not necessarily in the literal sense of the word); sometimes it may also mean "the world." By using that term (which, as a biblical category, goes with the adjective "eschatological"), it is possible to distinguish different eons in the history of the world, in the perspective of the history of salvation and in the perspective of eternity. Hence, one may speak of an old eon and a new eon, a present eon and a future eon, a good eon and a bad eon, an eon understood as the present life (i.e. life in the human body) and one understood as a future life. ${ }^{30}$

The master of time is God the Father, "the King of ages, immortal" (1 Tim 1:17), ${ }^{31}$ but also Christ, whose Incarnation-along with the entire Paschal Mystery-ushered in and led to the fullness of time. ${ }^{32}$

The New Testament regards Jesus Christ as the Center both in the theoretical model of linear time and in real ontological terms (cf. Gal 4:4). The Incarnation of the Word and the Passover that closely relates to it are interpreted not as the fulfillment and culmination of the history of salvation, but rather as a means and a starting point on the way towards the future. When interpreted in that manner, the Center has both a chronological layer and a historico-salvific layer within the economics of salvation, and eschatology becomes fully incorporated into the history and time of salvation. ${ }^{33}$

An important consequence of the Paschal Mystery, and in particular of the Mystery of the Ascension, is the existence-in eternity in Jesus Christ-of the human history with its temporal aspect. In the Person of Christ, earthly time and God's eternity are being transposed onto each other. ${ }^{34}$

The events in which Christ comes closer to his people for the sake of their salva-

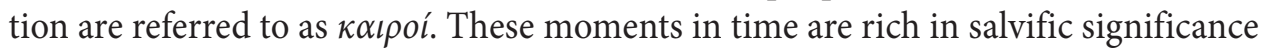
regardless of their duration. The history of salvation is a series of God's interven-

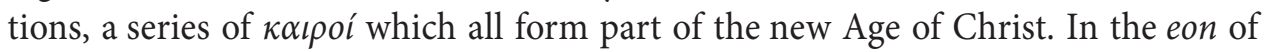
the New Covenant (which is also the eon of the Church), there is present not only the expectation of the people of the Old Covenant, but also the eternity, the $\tilde{\varepsilon} \sigma \chi \alpha \tau \alpha$ and the Second Coming (cf. Eph 1:10; 2 Pet 3:13). The second adventus of Christ is

30 See Léon-Dufour, Słownik Nowego Testamentu, 238, 250, 276; Jankowski, „Biblijna koncepcja czasu,” 27-29.

31 In line with the Old Testament, the New Testament also expresses God's dominion over time and His existence beyond any temporality through the use of the phrases "for ever" and-in an even greater manifestation of God's power-“for ever and ever" (cf. Luke 1:33; Rom 1:25; 16:27; 2 Cor 11:31; Gal 1:5; 1 Tim 1:17; Jude 25); see Schelkle, Teologia Nowego Testamentu, I, 89-94.

32 See Triacca, “Tempo e liturgia”, 1499-1500.

33 Cf. Liszka, Wpływ nauki, 74; Jankowski, „Biblijna koncepcja czasu,” 24-25.

34 Cf. Bartnik, Chrystus jako sens, 263. 
already being made real in the salvific present ushered in by the historical adventus: the first coming of the Son of God to earth. ${ }^{35}$

\section{Salvation in the Liturgy: God's Eternity in Time}

If the $\chi$ póvos of the New Testament leads to the understanding of the liturgy as a comprehensive remembrance and manifestation of the mystery of salvation that

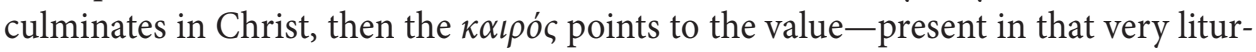
gy-of each separate celebration as an observance that, in and of itself, contains salvific power. In the same way as the history of salvation is an accumulation of $\kappa \alpha \iota \rho o$, the liturgy (as can be seen to the fullest extent in the cycle of the liturgical year) that

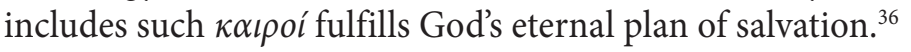

As Christ himself emphasized (cf. Mark 1:14-15) and Paul repeated many times after Him, with the coming of the Son of God to earth, His death and His resurrection, "the time is fulfilled, and the kingdom of God is at hand." While still living in the present eon ("the world that is evil"; cf. Rom 12:2; 1 Cor 1:20; 2:6; 3:18; 2 Cor 4:4; Gal 1:4), a Christian is to become transformed as a consequence of being grafted into the life and the time (eon) of Christ. The new time that has begun, the Christian time that lasts after the Death, Resurrection and Ascension of the Lord, will end on the day of the Second Coming.

This time of the Church is tightly joined to or even "interwoven" with the time of Christ as the one seated at the right hand of the Father. Hence, in liturgical celebrations, there occurs a symbiosis of human time with God's time and with eternity. ${ }^{37}$ God's time permeates human time, which thus becomes the time of salvation, the time of the anamnetic presence of the Paschal Mystery and Christ's salvific action; human time opens itself to God's time. The liturgy has a theological and cosmological significance: in every liturgical celebration, cosmic time joins with the salvific events and with the current history of every man. ${ }^{38}$

Just as God's entry into time and human history transformed and deified them, so in the eon of the Church - thanks to the liturgy and through the liturgy-the "profane history" becomes "sacred history." The celebration of the liturgy "until the end

35 See Bartnik, Chrystus jako sens, 268; Triacca, "Tempo e liturgia," 1495-1497; Hryniewicz, Zarys chrześcijańskiej teologii, II, 266; cf. Brzeziński, "Chrystus wczoraj i dziš," 273-298; Brzeziński, "Liturgiczny kairos," 117-123.

36 Cf. Augé, L'anno liturgico, 35-36;

37 In the Roman Missal of 2002, the word "time" occurs 75 times and the word "eternity" occurs as many as 385 times.

38 Cf. Augé, L’anno liturgico, 36-39; Cazelles, "Bible et temps liturgique"; Giglioli, "Cristo è il vero anno"; de Clerck, Zrozumieć liturgię, 136. 
of time" gives rise to a process of "Christification" of history, causing all history to become increasingly permeated with the presence of the Paschal Mystery of Christ. In the liturgy, there occurs not only an anticipation of the ultimate fullness, but also a true temporal coming together. As a result of the liturgical action, the world is being modeled and a new type of cosmic space-time curvature appears so that the point of the end of time leans more and more towards the point in time (moment) in which the liturgy is being celebrated. ${ }^{39}$

What took place in "that time" of the historic salvific events is simultaneously the liturgical present. Therefore, during liturgical celebrations which have an anamnetic dimension, we become the witnesses, partakers and celebrants of the events of the Paschal Mystery. Liturgical time is marked with the present ("right now") of God's salvation and with God's salvific presence that is being fulfilled "right now." In the liturgy, there is no difference between in illo tempore and hodie. Through God's eternity and extratemporaneity, the "Divine now" steps into the flow of created time. Christ's Paschal Mystery has crushed the structure of worldly chronology. ${ }^{40}$

Liturgical texts, especially the Euchology, very often accentuate the "today" For example, in the Collect of the Solemnity of the Resurrection, we pray with the following words: Deus, qui hodiérna die, per Unigénitum tuum, aeternitátis nobis áditum, devícta morte, reserásti, ${ }^{41}$ and in the First Preface of The Ascension, we thank God the Father as follows: Dóminus Iesus, Rex glórice, peccáti triumphátor et mortis, mirántibus Angelis, ascéndit hódie summa colórum. ${ }^{42}$

39 Cf. Liszka, Wpływ nauki, 143-145; Liszka, "Spotkanie czasu," 293.

40 It appears that Eastern theology does not attach significant importance to questions concerning the nature of the relationship between time and eternity. In fact, it only indicates that the line becomes blurred in the liturgy: time spills over, becomes deified, loses its autonomy, and disappears. Meanwhile, Western theologians-such as Odo Casel $(\dagger 1948)$, the brilliant creator of Mysterienlehre-underline the autonomy of time in an attempt to resolve the problem of how the timeless God is made present in the liturgy. In addition, they ask questions about the relationship between the structure of earthly history and the divine timelessness of Christ. In Casel's theology of mysteries, earthly time retains complete autonomy. Nevertheless, when he defined the term "mystery," Casel emphasized that it is inexplicably linked with certain salvific events that occurred in history and in time. Through the Incarnation that opened the Paschal Mystery of Christ, God entered the Xóvoc. As the liturgy is being celebrated, God acts from the outside, penetrating the "resistance" of time with His might. It is precisely at that "moment" of linear time in which the liturgy is being celebrated that God's might manifests itself and, above all, that the salvific event being celebrated-having only occurred once in the chronology of earthly time-becomes present "here" and "now" in a true, real and substantial manner. God's actions do not destroy that time, since it is the prerequisite foundation in which the event of Christ's Passion can become present. Christ as a Person becomes present with all of Himself, causing different stages of the Paschal Mystery to come into existence all at once, for there are no historical successions in Him; there is no "before" or "after" in Jesus. Therefore, the liturgy does not cause any deformation of chronological time and does not leave footprints of subsequent historical elements in it. Cf. Pałęcki, "Odo Casel”; Paprocki, "Obecność wymiaru eschatologicznego”; Liszka, Wpływ nauki, 148-149; Liszka, “Spotkanie czasu,” 296-297.

42 Missale Romanum, 535. 
In the liturgy, everything is sacred and falls outside the dominion of earthly life. Liturgical time no longer has the autonomous, earthly character: everything has, in a way, already been deified here on earth. The liturgy frees human beings from the dominion of worldly values, sacralizes everything and brings the participants into the presence of Divinity, into a situation in which time does not count. This is similar to the mystery of creation, since a new value is being created in the liturgy with the power of Christ. ${ }^{43}$

Liturgical time is "born" from the coming together of the salvific historical event and the liturgy that celebrates it. ${ }^{44}$ In other words, liturgical time is the history of salvation that lasts, a continuation of the biblical history of salvation and the biblical historico-salvific model of linear time; it is the history of salvation that is taking place "here" and "now." Liturgical time defined as an anamnetic continuation of the history of salvation has the same characteristics as the Christian liturgy, thus constituting the essence of that liturgy and endowing it with its fundamental meaning. The recurring liturgical time is the $\mu i \mu \eta \sigma \iota \varsigma$ of Christ's earthly life and, even more importantly, the $\dot{\alpha} v \alpha \dot{\alpha} \nu \eta \eta \sigma \varsigma$ of the Paschal Mystery of the Lord..$^{45}$ The relationship between time and liturgy stems from the nature of the latter.

Through the liturgical placement of the salvific events within a temporal framework and the anamnesis of these events in a specific space-time, human beings are given an opportunity to constantly encounter God and become included-thanks to His initiative-in the salvation that He grants. The work of salvation historically done by Christ has manifested itself in liturgical celebrations. With the passage of astronomical time, salvific time "inches forward" towards "point Omega," that is towards the Second Coming. Every year, we take an unrepeatable and irreversible step in our earthly pilgrimage - with Christ and through Christ-to the House of the Father, the final destination in our worldly journey.

Thanks to the liturgy, and above all to the sacramental liturgy and the Liturgy of the Hours, we therefore do not need to "regret" or "worry" that we are not living in the time of Christ, since-through the presence of the Savior and His Mystery-all the salvific events of two thousand years ago are present "here and now." They are really and effectively present whenever Christ as the Head of the Church and His entire Mystical Body celebrate the sacred liturgy of the Church. This presence, making the past real hic et nunc, anticipates the eschatic future: the Heavenly Jerusalem. ${ }^{46}$

43 Cf. Liszka, "Spotkanie czasu," 294-295.

44 According to Giorgio Bonaccorso, this "coming together" takes place at three basic levels: liturgy as a moment in linear time, liturgy as a mode of existence of time and liturgy as the time of celebration. Cf. Bonaccorso, Celebrare la salvezza, 187-193; Bonaccorso, "Nuovi modelli interpretativi"; Bonaccorso, Il rito e l'Altro, 40-45. 


\section{Time in Liturgical Theology vs. Time in Physics: An Attempt at Juxtaposition}

The belief that time is both sacral and sacred-especially during the celebration of the sacred rites-has been widespread since the earliest of time. This exceptionality of time was recognized in the ancient mystery religions and observed by the greatest thinkers of antiquity, although many of them - without knowing the true Godcould only relate to the deities and mythological events familiar to them. Nevertheless, in their deliberations, they generally perceived worldly time in the context of eternity and otherworldly happiness. ${ }^{47}$

Starting with Plato ( $† 347$ BC) and Aristotle ( $† 322$ BC), the notion of objective time or physical time began to develop in philosophical thinking and, subsequently, also in theological thinking. This notion has remained a dominant concept in scholastic philosophy and theology, and can be found in the works of such thinkers as St. Albert the Great $(\dagger 1280)$ and St. Thomas Aquinas (†1274). ${ }^{48}$

In accordance with the centuries-old tradition, theology has typically treated time as a measure of motion and as an isolable characteristic of the cosmos created by God. Time is not linked to substantiality (unlike matter) and is regarded merely as an accident. However, with the changes in the understanding of both substance and matter, the meaning of the notion of time has also changed - not only as regards its structure, but also as regards its beingness. New theories no longer treat time as an accident of material substance, but rather ascribe to it the same ontological meaning as to matter. According to modern-day physics, time does not exist as a standalone, clearly distinguishable and measurable reality. ${ }^{49}$

When Gottfried W. Leibniz ( $† 1716)$ and Isaac Newton $(\dagger 1727)$ were formulating the theory of absolute time, they still attributed the quality of absolute reality to time in the same manner as they did with respect to space. Time is a continuum that flows from the past to the future: immutable, homogenous, irreversible and unidimension-

47 The circular concept of time (i.e. the concept of time as a closed circle) represented by these thinkers was generally not accepted in Judaism and firmly rejected in Christianity. The latter adopted a linear concept of time. Today, it is reflected in the modern theories of physical cosmology that pertain to the direction of the passage of time. See Francoeur, Horyzonty ewolucji, 16; Wciórka, Filozofia przyrody, 58-60. The linear concept of time is supported by the law of increasing entropy (which states that in a closed system of bodies acting on one another, entropy may only increase and never decrease) and by the phenomenon of the spatial expansion of the universe. Interestingly, the linear concept of time was already widespread among Chaldeans in the eight century BC. See Auf der Maur, Le celebrazioni, 39-42.

48 In his attempt to explain the "mode of existence" of eternity (aeternitas) in time (tempus), Aquinas used the term "aeviternity" (aevum; aeviternitas), placing it "between" time and eternity. When compared to time, aeviternity appears to be eternity, but when compared to eternity, it appears to be time. The question of whether liturgical time can be compared-by using a certain formal analogy - to Thomas's aevum remains open. See Kowalewska, "Aevum quod est angeli duratio."

49 Cf. Wojciechowski, "Scholastyczne i niescholastyczne dyskusje”; Liszka, Wplyw nauki, 8; Tempczyk, "Czas we współczesnej fizyce," 231-244. 
al; it is an absolute duration. As such, it is real regardless of the motion of matter or human perception. The problem of absolute time and relative time is associated with the dependency of time upon the physical processes which it measures. The idea of absolute time that is independent of the processes and phenomena that occur within it was formulated by Galileo ( $\dagger 1642)$ in connection with his findings concerning the relationship between the results of observation of the motion of a specific body in relation to different frames of reference. According to the Italian physicist, astronomer and philosopher, the time of a phenomenon being observed by different observers flows identically for each of them, regardless of the frame of reference within which the phenomenon is being observed. The "Galilean transformation" was built upon by I. Newton in his mechanics. Being a proponent of extreme realism in the interpretation of time, Newton regarded time as a reality that is independent of material bodies, an intrinsic being that is independent of the realities it embraces, a being that exists in the same way as substance and is capable of enduring even in the absence of the events that it embraces. In other words, he adopted the concept of transcendent and absolute time to describe events in absolute space. Treating time as a substantial being, Newton was nevertheless aware that it must exist in a different manner than the ordinary material substances whose mode of being is defined by time (together with space). Newton explained the ontic nature of time by saying that this was the way in which God perceives the world. However, since God is an Absolute Being, the cognitive categories appropriate to Him are, at the same time, a definition of the mode of existence of the beings which He is cognizing. In that respect, the Newtonian view of time is, in a sense, similar to the concept of time adopted by Immanuel Kant ( $\dagger 1804)$, who considered it "a form of sensory experience." Newton’s concept of time remained dominant in physics until the twentieth century, when it was displaced by the special theory of relativity formulated by A. Einstein ( $† 1955)$. The latter used the assumption that light travels at the same speed in relation to any inertial frame of reference to derive conclusions which significantly changed the existing views of space and time. ${ }^{50}$

According to the theory of relativity, time is local, i.e. different in different places in space-time. Moreover, space-time is not static: as a whole, it is treated "statically," but its "interior" is in constant and complicated motion: both space and time depend on the presence of matter. There are places where time takes extreme values: zero and

50 Cf. Wciórka, Filozofia przyrody, 54-58; Mazierski, Elementy kosmologii, 188-208; Gawin, "Koncepcje czasu i przestrzeni". Many scholars have raised the issue that Einstein's theory of relativity exhibits basic difficulties when it comes to measuring time due to the existence of different frames of reference. Besides that, the theory of relativity itself does not entail any philosophical consequences, so there should be no contradiction between that theory (as a physical one) and the philosophical concept of time. And yet, the theory of relativity gives rise to certain philosophical problems that pertain to space and time. One such problem is the existence (or nonexistence) of a universally objective metric structure of time, since objective measurement of time is generally impossible. See Melsen, Filozofia przyrody, 275-279. 
infinity. The zero of time is related to the beginning of the Universe, i.e. to the first occurrence of the physical matter. In turn, in black holes the time is infinity: never goes ahead. But the spirit is not the matter, and is not governed by the time arrow.

Therefore, the time during which the liturgy is being celebrated cannot be regarded solely as a stream of points flowing uniformly in the same direction. Even if history was merely a linear fragment of space-time, the very fact of it being a fragment would mean that it is immersed in something larger, something with a greater number of dimensions. And even if the liturgy is part of the axis of time, this part (like the entire straight line representing time) is immersed in the great space-time and is therefore subject to the laws that prevail within it. And these are not physical laws of space and time, anymore.

In consequence, there is nothing to prevent the same liturgy from being celebrated simultaneously and diachronically in relation to the historical Paschal Mystery of Christ that it commemorates in multiple places around the globe thanks to the timeless power of the Holy Spirit, and likewise, there is nothing to prevent the same salvific mysteries from being repeated in a cyclically defined order during the day or during the astronomical year. ${ }^{51}$

From within the dimension of linear (worldly and historical) time, it is not possible to make any observation of what is happening in the fragment of the multidimensional space-time that contains the liturgy being celebrated. However, an extreme space-time curvature occurs in the liturgy, causing the place and time in which it is being celebrated to come into contact with the place and time of Christ's Paschal Mystery. Or, more precisely, the liturgy is not subject to the space-time framework. Therefore, every liturgy is a manifestation of the "fullness of time." Obviously, this biblical term only applies to the supernatural reality and not to the natural temporal structure. ${ }^{52}$

51 Cf. Brzeziński, “Chrystus wczoraj i dziś,” 243-272.

52 Based on empirical research and theoretical reflection, a "metascience" was created in modern physics, namely philosophy of time (the new discipline is part of the broadly defined field of physics, and is independent of the autonomous disciplines of philosophical cosmology and natural philosophy). Its goal is to attain the most appropriate and fullest possible understanding of the structure of time as an important component of the universe. Modern physics sees a close relationship between all parameters of the universe: energy, motion, matter, space and time, a classic example in that regard being Albert Einstein's aforementioned theory of relativity. In fact, today's physics is developing towards the creation of a unified theory that links all the force fields which actually exist in the universe to space-time geometry. In parallel with this trend, quantum theories are developing, although it remains problematic to formulate a theory that combines the geometric description (continuous and dense) with the quantum description. The macroscopic theory of gravitation describes the modeling of time across the entire universe, whereas the quantum theories describe the microworld and reveal the structure of time in its most minute detail. The development of mathematics (especially topology) has also made it possible to construct theoretical models that describe the structure of the universe in an increasingly versatile manner, taking into account the physical structure of time. See Liszka, Wpływ nauki, 26-47; for a detailed discussion of the subject, see Tempczyk, Fizyka a świat realny; Heller, "Ontologiczne zaangażowanie." 


\section{DANIEL BRZEZIŃSKI}

The liturgical mode of existence of the salvific mysteries thanks to which the Mystery of Christ is being actualized "here and now" is timeless and metahistorical, since it transcends both space and time. ${ }^{53}$ In liturgical anamnesis, the past, the present and the future combine. The past becomes the present and the present encompasses the future. Those participating in the liturgy become contemporaries of the salvific event in question and, at the same time, anticipate the future of the end of time. Hence, with regard to the anamnesis that takes place in the liturgy, one should speak of detemporalization, transtemporality and supertemporality, as well as of extraspatiality and superspatiality. ${ }^{54}$

Attempts to explain the relationship between the temporal structure of the liturgy and Jesus Christ as the one being made present in it may have failed due to the exclusive adoption of a model of time that consists of a straight line directed towards positive infinity. Meanwhile, it is important to remember that the manner in which Jesus Christ comes into contact with worldly time in the liturgy can only be explained-if not completely, then at least partially-when there exists, at least in some analogous sense, a temporal structure in the resurrected Jesus and/or if there exists some openness in the structure of worldly time that is receptive to coming into contact with Christ's supertemporality, extratemporality and eternity, as has been the subject matter of our reflection. In this context, a wealth of material for consideration-opening new horizons for theology, too-is being provided by modern physics, which makes it possible to treat the time of the celebration of the liturgy as a "singular place," some peculiar time-space curvature "where God's intervention is particularly condensed." 55

\section{Conclusion}

The extraordinary nature of the phenomenon of time has been at the forefront of human thought-including theological reflection-for centuries. Today, time is increasingly becoming the subject of particular interest for liturgical theology, a discipline that relies on anthropological and religious reflection as well as on the achievements of biblical exegesis and theology. One has to admit, however, that despite the efforts being made and the theses and hypotheses being put forward in an attempt to explain or describe the meeting of time and the liturgy, one is always faced with God's mystery that escapes purely human observation and speculation. In that respect, the Divine Revelation and the biblical concept of time come to aid.

\footnotetext{
Cf. Rosso, Un popolo, 260.

Cf. Nadolski, Leksykon liturgii, 89.

Cf. Sedlak, Technologia Ewangelii, 198; Liszka, Wptyw nauki, 150-151; Liszka, "Spotkanie czasu," 298-301.
} 
In the light of the Holy Scripture, there is no doubt that in the liturgy, there occurs a meeting in mysterio of human time and God's eternity; a spatiotemporal opening to God's infinity and His effective salvific action. Christ united in Himself matter and Divinity, time and timelessness, thus overcoming the dualism associated with these notions.

As clearly demonstrated by theological and liturgical studies, it is above all in the liturgy of the Church that human time connects in the most intimate manner with God's salvific action. In the Christian liturgy as an anamnesis of the Mystery of Christ and of God's entire economics of salvation, eternity can be reached through time. When the Son of God stepped into human existence, time became deified

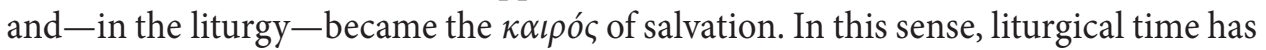
a real salvific dimension.

Thanks to the time in which we live and through earthly time, we can participate in the extratemporal and supertemporal salvation of man by God. This is how the "fullness of time" is accomplished here on earth in the liturgy of the Church; this is where the mutual transposition of earthly time and God's time manifests itself.

Through the liturgical placement of the salvific events within a temporal framework and the simultaneous anamnesis of these events in a specific space-time, human beings are given an opportunity to constantly encounter the active God and benefitthanks to His initiative-from the salvation that He grants. In this understanding, the liturgy - in which the laws of physics as we know them become suspended-can be compared to a "Bermuda triangle" of a kind, bearing in mind all the deficiencies of any analogy. In the liturgy of the Mystical Body of Christ, all spatial and temporal limitations of the universe become suspended or transformed. The Christian liturgy is an otherworldly act of salvation in worldly space and time, a salvific "intersection" of time and eternity.

As it appears, our religious and theological intuition and our knowledge of the nature of time are increasingly being validated by modern physics, at least in terms of a formal analogy. In the liturgy, time does not have an autonomous, earthly character. Similarly, in modern-day physics, time is no longer understood as an absolute duration, a standalone, clearly distinguishable and measurable reality. Instead, modern physics makes it possible to treat liturgical time as a "singular place" and as some peculiar time-space curvature. The salvific dimension of time in the Christian liturgy is nothing other than that physical "singularity," offering man a real possibility of coming into contact with Christ's supertemporality, extratemporality and eternity. 


\section{DANIEL BRZEZIŃSKI}

\section{Bibliography}

Auf der Maur, H., Le celebrazioni nel ritmo del tempo. I. Feste del Signore nella settimana e nellanno (Leumann: Elle Di Ci 1990).

Augé, M., L’anno liturgico. È Cristo stesso presente nella sua Chiesa (Città del Vaticano: Libreria Editrice Vaticana 2009).

Augé, M., “Teologia dell'anno liturgico," L’anno liturgico. Storia, teologia e celebrazione (red. A.J. Chupungco) (Anàmnesis 6; Genova: Marietti 1989) 9-34.

Augustynek, Z., Natura czasu (Warszawa: PWN 1975).

Bartnik, C.S., Chrystus jako sens historii (Wrocław: Wydawnictwo Wrocławskiej Księgarni Archidiecezjalnej 1987).

Bartnik, C.S., Historia ludzka i Chrystus (Katowice: Księgarnia św. Jacka 1987).

Bartnik, C.S., Teilhardowska wizja dziejów (Lublin: Towarzystwo Naukowe KUL 1975).

Baumgartner, H.M. - Wildfeuer, A.G, “Czas," Leksykon religii. Zjawiska - dzieje - idee (ed. H. Waldenfels) (Warszawa: Verbinum 1997) 70-71.

Bergamini, A., Cristo, festa della Chiesa. Storia, teologia, spiritualità, pastorale dellanno liturgico (Cinisello Balsamo: Edizioni Paoline 1991).

Bielecki, S., "Kairos (1)," Encyklopedia katolicka (eds. A. Szostek et al.) (Lublin: Towarzystwo Naukowe KUL 2000) VIII, 334.

Bielecki, S., "Kairos (3)," Encyklopedia katolicka (eds. A. Szostek et al.) (Lublin: Towarzystwo Naukowe KUL 2000) VIII, 335-337.

Bieliński, K., “Czas w podwójnym dziele Łukasza,” Verbum Vitae 35 (2019) 187-216.

Bonaccorso, G., Celebrare la salvezza. Lineamenti di liturgia (Padova: Messaggero 1996).

Bonaccorso, G., Il rito e l'Altro. La liturgia come tempo, linguaggio e azione (Città del Vaticano: Libreria Editrice Vaticana 2001).

Bonaccorso, G., "Nuovi modelli interpretativi del tempo: provocazioni alla riflessione liturgica," Rivista Liturgica 77 (1990) 359-386.

Bruni, G.C., "La concezione biblica del tempo," Servitium 9 (1975) 329-343.

Brzeziński, D., "Chrystus wczoraj i dziś, i na wieki". Anamnetyczny wymiar roku liturgicznego, 2 ed. (Toruń: Toruńskie Wydawnictwo Diecezjalne - Pelplin: Bernardinum 2015).

Brzeziński D., "Liturgia skarbem Kościoła. Historiozbawczy wymiar liturgii chrześcijańskiej," O bogactwach Kościoła (red. M. Chojnacki - J. Morawa - A.A. Napiórkowski) (Kraków: Salwator 2014) 13-25.

Brzeziński, D., "Liturgiczny kairos czasem eschatycznej nadziei i jej wypełnienia," "Chlubimy się nadzieją chwały Bożej” (Rz 5,2). Księga dedykowana ks. prof. dr. hab. Janowi Decykowi (red. K. Filipowicz) (Warszawa: Wydawnictwo UKSW 2016) 117-129.

Brzeziński, D., "Rytualizacja mitu w starożytnych religiach misterycznych: ku zrozumieniu liturgii chrześcijańskiej," Studia Włocławskie 21 (2019) 565-583.

Brzeziński, D., “The Notion of Myth in History, Ethnology and Phenomenology of Religion," Teologia i Człowiek 32/4 (2015) 13-26.

Brzeziński D., "Wokół teologicznego sensu liturgii: przełamywanie stereotypów," Teologiczne Studia Siedleckie 12 (2015) 267-280.

Burns, A.L., "Two Word for 'Time' in the New Testament," Australian Biblical Review 3 (1953) 7-22. 
Cazelles, H., “Bible et temps liturgique. Eschatologie et anamnèse," La Maison-Dieu 147 (1981) $11-28$.

Cecolin, R., "Le nuove concezioni del tempo e la Bibbia," Rivista Liturgica 77 (1990) 387-413.

de Clerck, P., Zrozumieć liturgię (Kielce: Jedność 1997).

De Vries, S., "Il tempo nella Bibbia," Concilium 2 (1981) 19-39.

Eliade, M., Aspects du mythe (Paris: Gallimard 1963).

Eliade, M., Mythes, rêves et mystères (Paris: Gallimard 1989).

Francoeur, R., Horyzonty ewolucji (Warszawa: Pax 1969).

Gale, M.R., The Language of Time (London: Routledge \& Kegan 1968).

Gawin, A., "Koncepcje czasu i przestrzeni - czasoprzestrzeni - w fizyce. Ujęcie retrospekcyjne," Czas i kalendarz (red. Z.J. Kijas) (Kraków: Wydawnictwo Naukowe PAT 2001) 407-433.

Giglioli, P., "Cristo è il vero anno liturgico," Lanno liturgico (eds. Centro di Azione Liturgica) (Celebrare il mistero della salvezza 1; Roma: CLV 1998) 25-42.

Glasswell, M.E., “The New Testament View of Time,” Communio Viatorum 16 (1973) 249-255.

Heller, M., "Ontologiczne zaangażowanie współczesnej fizyki," Analecta Cracoviensia 18 (1986) 3-20.

Hryniewicz, W., Zarys chrześcijańskiej teologii paschalnej. II. Nasza Pascha z Chrystusem (Lublin: Towarzystwo Naukowe KUL 1987).

Jankowski, A., “Biblijna koncepcja czasu," Czas i kalendarz (red. Z.J. Kijas) (Kraków: Wydawnictwo Naukowe PAT 2001) 21-34.

Jasiński, A.S., "Prorockie ujęcie czasu Izraela - perspektywa Księgi Ezechiela," Verbum Vitae 35 (2019) 77-119.

Jeziorski, S., "Liturgia a percepcja i przeżywanie czasu w dobie postmodernizmu," Verbum Vitae 35 (2019) 435-457.

Jojko, B., "Eternity and Time in the Gospel of John," Verbum Vitae 35 (2019) 245-278.

Juszczak, W., Pani na Żurawiach. I. Realność bogów (Kraków: Aureus 2002).

Karczewski, M., “Znaczenie terminu $̋ \rho \alpha$ ('godzina') w Apokalipsie Janowej”, Verbum Vitae 35 (2019) 279-306.

Karwasz, G., Scienza e fede. Un breve manuale (Roma: Aracne 2019).

Kerényi, C., Eleusis. Archetypal Image of Mother and Daughter (Princeton, NJ: Princeton University Press 1967).

Kijas, Z.J., “Czas i kalendarz," Czas i kalendarz (red. Z.J. Kijas) (Kraków: Wydawnictwo Naukowe PAT 2001) 9-18.

Klein, É., Czas (Katowice: Książnica 1999).

Kowalewska, M., “Aevum quod est angeli duratio. Wiekuistość, czyli między wiecznością a czasem," Ethos 25/3 (2012) 117-133.

Kręcidło, J., "Jezus a czas w perspektywie antropologii kulturowej," Verbum Vitae 35 (2019) 167-185.

Léon-Dufour, X., Słownik Nowego Testamentu, 2 ed. (Poznań: Księgarnia św. Wojciecha 1986).

Liszka, P., "Spotkanie czasu z wiecznością w liturgii," Ateneum Kapłańskie 85/2 (1993) 292-301.

Liszka, P., Wplyw nauki o czasie na refleksję teologiczna (Warszawa: Palabra 1992).

Manek, J., "Biblical Concept of Time and our Gospels," New Testament Studies 6 (1959) 45-51.

Marsili, S., "Il 'tempo liturgico' attuazione della storia della salvezza," Rivista Liturgica 57 (1970) 207-235. 


\section{DANIEL BRZEZIŃSKI}

Mazierski, S., Elementy kosmologii filozoficznej i przyrodniczej (Poznań - Warszawa - Lublin: Księgarnia św. Wojciecha 1972).

McLeish, T., "Commentary: Thinking differently about science and religion," Physics Today 71/2 (2018) 10-12.

van Melsen, A.G., Filozofia przyrody (Warszawa: Pax 1963).

Mielcarek, K., “Termin $\sigma \eta \dot{\mu} \mu \rho o v$ ('dziss') w dziele Łukaszowym. Zarys współczesnych badań," Verbum Vitae 35 (2019) 217-244.

Missale Romanum ex decreto Sacrosancti Ecumenici Concilii Vaticani II instauratum auctoritate Pauli PP. VI promulgatum Ioannis Pauli PP. II cura recognitum, editio typica tertia (Città del Vaticano: Libreria editrice vaticana 2002).

Mondin, B., Mito e religioni. Introduzione alla mitologia religiosa e alle nuove religioni (Milano: Massimo 1997).

Nadolski, B., "Christus heri, hodie et in saecula saeculorum. Uobecniająca pamięć misterium paschalnego," Ethos 25/3 (2012) 21-35.

Nadolski, B., Leksykon liturgii (Poznań: Pallottinum 2006).

Napora, K., “Czas w kapłańskim opowiadaniu o stworzeniu: dzień pierwszy (Rdz 1,3-5)," Verbum Vitae 35 (2019) 13-37.

Neuenzeit, P., “Zeit," Bibeltheologisches Wörterbuch (red. J. B. Bauer) (Graz - Wien - Köln: Styria 1967) II, 1534-1539.

Otto, W.F., Mythos und Welt (Stuttgart: Klett 1962).

Otto, W.F., Theophania. Der Geist der altgriechischen Religion, 3 ed. (Hamburg: Rowolht 1993).

Pałęcki, W., "Odo Casel," Leksykon wielkich teologów XX/XXI wieku (red. J. Majewski - J. Makowski) (Warszawa: Biblioteka „Więzi” 2006) III, 49-61.

Paprocki, H., "Obecność wymiaru eschatologicznego w doczesności. Punkt widzenia prawosławnego," Ethos 25/3 (2012) 36-45.

Parchem, M., “Periodyzacja historii w Księdze Daniela," Verbum Vitae 35 (2019) 121-144.

Perani, M., "La concezione del tempo nell'Antico Testamento," Sacra Doctrina 87 (1978) 193-242.

Perani, M., "La concezione ebraica del tempo. Appunti per una storia del problema," Rivista Biblica 26/4 (1978) 401-421.

Ratzinger, J., Der Geist der Liturgie. Eine Einführung (Freiburg im Breisgau: Herder 2000).

Rosso, S., Il segno del tempo nella liturgia. Anno liturgico e liturgia delle ore (Leumann: Elle Di Ci 2004).

Rosso, S., Un popolo di sacerdoti. Saggio di liturgia fondamentale (Roma: LAS 1999).

Schelkle, K.H., Teologia Nowego Testamentu. I. Stworzenie. Świat - czas - człowiek (Kraków: Wydawnictwo Apostolstwa Modlitwy 1984).

Sedlak, W., Technologia Ewangelii (Poznań: Pallottinum 1989).

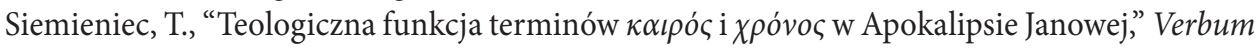
Vitae 35 (2019) 307-342.

Stachowiak, L., "Kairos (2)," Encyklopedia katolicka (eds. A. Szostek et al.) (Lublin: Towarzystwo Naukowe KUL 2000) VIII, 334-335.

Szram, M., “Wszystko ma swój czas’. Patrystyczna egzegeza Księgi Eklezjastesa 3, 1-8," Verbum Vitae 35 (2019) 345-372.

Tempczyk, M., “Czas we współczesnej fizyce,” Ethos 25/3 (2012) 231-244. 
Tempczyk, M., Fizyka a świat realny. Elementy filozofii fizyki (Warszawa: PWN 1986).

Triacca, A.M., "Tempo e liturgia," Nuovo dizionario di liturgia (eds. D. Sartore - A.M. Triacca) (Cinisello Balsamo: Edizioni Paoline 1988) 1494-1508.

Wciórka, L., Filozofia przyrody (Poznań: Wydawnictwo PWT 1993).

Whitrow, G.J., Czas w dziejach. Poglady na czas od prehistorii po dzień dzisiejszy (Warszawa: Prószyński i S-ka 2004).

Wojciechowski, T., "Scholastyczne i niescholastyczne dyskusje nad naturą czasu," Analecta Cracoviensia 3 (1971) 83-115.

Zachariasz, A.L., “Czas jako kategoria kulturowa," Czas, wartości i historia (red. Z.J. Czarnecki) (Lublin: Wydawnictwo UMCS 1990) 33-55. 
